\title{
Development of E-Book Based on Local Sumut Culture in High Class IPS Education Courses PGSD UNIMED
}

\author{
$1^{\text {st }}$ Yusra Nasution ${ }^{1}, 2^{\text {nd }}$ Husna P. Tambunan ${ }^{2}, 3^{\text {rd }}$ Risma Sitohang $^{3}$ \\ \{yusranasution@unimed.ac.id ${ }^{1}$, husnatambunan@gmail.com ${ }^{2}$, rismasitohang@gmail.com ${ }^{3}$ \} \\ Department of Primary School Teacher Education, Faculty of Science Education, Universitas Negeri \\ Medan, Indonesia ${ }^{1,2,3}$
}

\begin{abstract}
This study aims to: (1) describe the results of expert tests regarding the North Sumatran Local Culture-Based E-Book product in the Social Sciences Education Course for Higher Class PGSD Unimed, and (2) describe the use of the North Sumatran Local Culture-Based E-Book development in this course. Unimed PGSD High Class Social Studies Education. The research method used is a research and development (R\&D) model with a Van den Akker development model by developing an e-book for High Class Social Studies Education based on North Sumatran Local Culture. The location of the research was carried out in the PGSD FIP Unimed study program which was located on Jl. Willem Iskandar / Pasar V, Medan. The population of this study was all students of PGSD Unimed Stambuk 2020 totaling 225 students consisting of 11 (AK) regular and extension classes. The sample of this research was carried out in a class program and one class was selected, namely Class B Regular 2020, totaling 40 students. The results showed that the North Sumatran Local Culture-Based E-Book on the PGSD High Class Social Studies Education Course that was developed was validated by material and media experts. The average score of the second phase material experts was $71 \%$ with the "Fair" criteria and the average score of the second phase material experts was $90.6 \%$ with the "Very feasible" criteria. And the results of the media experts assessment were $91.43 \%$ with the criteria of "Very decent". In the trial of the E-book product to students, the pretest results with completeness $23.07 \%$ and post-test results with completeness $96.15 \%$.
\end{abstract}

Keywords: E-Book, Local Culture, Social Studies, High Class.

\section{Introduction}

The development of standardized textbooks through innovation needs to be done to fulfill good quality textbooks that can improve human resources. College textbooks of good quality and standard will be able to help students in learning, so that CPLU and CPMK can be achieved. Through high-grade elementary social studies education courses, students are expected to be able to master facts, concepts and generalizations of social studies learning. With high school social studies subjects, students are also expected to be able to design and implement learning approaches in learning in elementary schools, and students are expected to be able to design and develop evaluation tools in elementary social studies learning.

Connected with the spread of the corona virus pandemic or COVID-19 in Indonesia, many universities and schools have stopped the face-to-face learning process. So that researchers face a new phenomenon regarding the learning system. Based on the announcement madeMinister of Education and Culture Nadiem Makarim admitted that he was 
studying the possibility of implementing an emergency curriculum due to conditions that required studying at home during the virus pandemic corona (Covid-19). In addition, students must also be ready to adapt to changes in learning regulated by schools and universities. Remote learning can be seen as more freely and flexibly accessed from home.

In addition, in Law no. 20 of 2003 it is stated thateducation national based on Pancasila and the State Constitution Republic of Indonesia 1945. One of the Pancasila points that can be applied is develop a sense of love for the homeland and nation. Based onstatement on, educational activities that occur in Indonesia must be appropriate, based on, and is an effort to implement the values of Pancasila. Matter it is trying so that the spirit of nationalism of students can continue to grow and develop. This is due to the extinction of local wisdom thatIt is in each-each area so it needs an early introduction through young generation.

In line with this statement, the introduction of regional culture or potential is important. This is because the spirit of nationalism will emerge when an individual has been able to internalize the love of his area in everyday life. In an effort to develop values in citizens through education, one of the strategies adopted is through the integration of local wisdom materials in subjects especiallyhigh-grade elementary social studies education courses. Naisbit [1] says that the era of globalization will bring up a global image with a global culture that directly opposes local culture. The information and communication revolution as a direct impact of advances in science and technology has removed regional and territorial boundaries, so thatfor certain communities this condition must be addressed with hurry up and comprehensive so that they don't lose themselves nation.

Based on the explanation above, the step of material integration wisdom local in the subjects of high-grade elementary social studies education courses through the development of local culture is expected able to cultivate the love of the younger generation towards the potential of the region so that they want to participate in preserving local wisdom in the area. Local culture can also be used as a means to instill moral values which develop in the community, considering that local wisdom is also full of values moral capable of forming a good personality. With thus, the integration of local wisdom in learning is considered capable of make the younger generation participates in contributing to maintaining the superior potential of the region as well as instilling good moral values and developing in society to form a complete human being. In developing local wisdom there are also other functions that are useful both for humans as individual, social, and human beings who are in contact with the environment. Among them, functions for the conservation and preservation of natural resources, for the development of human resources, for the development of culture and science, have social meanings such as communal/relative integration ceremonies. Other functions can also mean ethics and morals as well as kinship, for example bringing back regional traditions in the form of packaging Social Science material that contains wisdom.

Based on the phenomenon that is happening right now, when facing the Corona pandemic that doesn't know when it will end. Researchers provide one way that can be used to carry out the online learning process is by developing an E-Book Development Based on North Sumatran Local Culture in the Social Sciences Education Course for Higher Class PGSD Unimed. In this study, researchers designed a valid high-grade Social Science Education textbook used by lecturers in the learning process according to the characteristics of students and the potential of North Sumatra so as to increase creativity and student learning outcomes. This textbook is also seen from the accuracy of the content which is the validation or validity of the contents or the truth of the contents scientifically and the alignment of contents based on the value system adopted by a society or nation. Content validation shows that teaching materials are not developed carelessly. The content of teaching materials is developed based 
on the concepts and theories that apply in the field of science and in accordance with the development of the field of science and the results of empirical research conducted in the field of science. Thus, the content of teaching materials can be justified scientifically, correct from a scientific point of view. Content validation is very important to note so that teaching materials do not spread misconceptions or misconceptions that students can take to the next level of education or into their lives. According to Belawati [2] to be able to maintain content validation, in the development of teaching materials, teachers must always use reference books or library materials, theories and concepts that apply in a field of science as well as the latest developments in a field of science. Content harmony means the conformity of the content of teaching materials with the value system and philosophy of life prevailing in the country and society in which students are located. In this case, researchers develop teaching materials that can be used as guidelines for lecturers in making teaching materials. The teaching materials developed include learning objectives, logical and systematic presentation of material and sentences that are easily understood and understood by lecturers and students. Based on the explanation above, the title of this research is the Development of an E-Book Based on North Sumatran Local Culture in the Social Sciences Education Course for Higher Class PGSD Unimed.

\section{Method}

This research method is a research and development (R\&D) method. This method was used because it developed an e-book for High Grade Social Studies Education Based on North Sumatran Local Culture. In this study, following the research and development model of Van den Akker [3] which includes 3 main aspects of substantive, procedural and theoreticalempirical. (1) Substantive aspects, validity, practicality, and effectiveness. (2) Aspects of procedures, related to development activities. (a) A front-end analysis to describe the starting situation (context, available theory, and research results), (b) A formative analysis to develop, evaluate, and revise the materials. (3) Theoretical-empirical aspects: related to the theory used and the field data produced. The Van den Akker model is a continuous circle. Each element of development is directly related to the revision activity. The development of an e-book for High Grade Social Studies Education Based on North Sumatran Local Culture can be started from any element in the cycle. Researchers used the six elements contained in the Van Den Akker development model, namely: (1) Preliminary Analysis, (2) Expert and teacher evaluation, (3) Small-scale trial, (4) Empirical data, (5) Reflection and revision, (6) Tracing model. The sequence of steps for developing teaching and learning short stories texts and LAS based on the Van Den Akker research and development model can be seen from the following figure: Researchers used the six elements contained in the Van Den Akker development model, namely: (1) Preliminary Analysis, (2) Expert and teacher evaluation, (3) Small-scale trial, (4) Empirical data, (5) Reflection and revision, (6) Tracing model. The sequence of steps for developing teaching and learning short stories texts and LAS based on the Van Den Akker research and development model can be seen from the following figure: Researchers used the six elements contained in the Van Den Akker development model, namely: (1) Preliminary Analysis, (2) Expert and teacher evaluation, (3) Small-scale trial, (4) Empirical data, (5) Reflection and revision, (6) Tracing model. The sequence of steps for developing teaching and learning short stories texts and LAS based on the Van Den Akker research and development model can be seen from the following figure: 


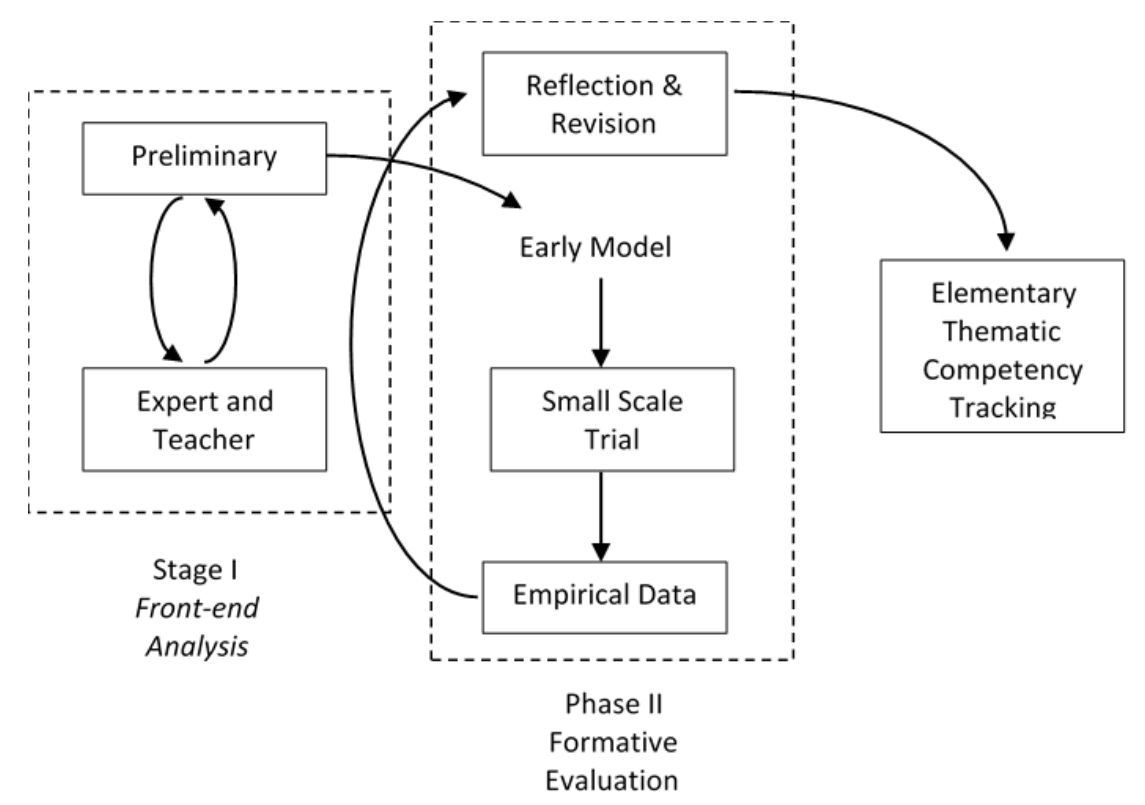

Fig. 1. Research and development model diagram [3].

The location of the research was carried out in the PGSD FIP Unimed study program which was located on Jl. Willem Iskandar / Pasar V, Medan, North Sumatra - Indonesia. The population of this study was all students of PGSD Unimed Stambuk 2020 totaling 225 students consisting of 11 (A-K) regular and extension classes. The sample of this research was carried out in a class program and one class was chosen, namely Class B Regular 2020, totaling 40 students.

\section{Results and Discussion}

The media validation stage is carried out by the validator by assessing aspects of content or content, design, appearance, use, presentation, language, aspects of material content, presentation of learning materials. The validation results from the experts are used as the basis for revising the North Sumatran Local Culture-Based E-Book on the Higher Class Social Studies Education Course. The revision is useful so that the E-Book Based on the Local Culture of North Sumatra on the Higher Class Social Science Education Course that is made gets a decent product. The results of the evaluation of the North Sumatran Local CultureBased E-Book product in the Higher Class Social Studies Education Course can be seen from the assessment of the validator who is two experts from the State University of Medan at the Faculty of Education. The following are the results of product validation that have been obtained from material experts. 
Table 1. Results of Phase 1 Material Expert Validation.

\begin{tabular}{rlccc}
\hline No & \multicolumn{1}{c}{ Aspect } & Score & Average Score & Information \\
\hline 1. & $\begin{array}{l}\text { Aspects of Material } \\
\text { Content }\end{array}$ & $75 \%$ & & \\
2. & $\begin{array}{l}\text { Aspects of material } \\
\text { presentation }\end{array}$ & $70 \%$ & $71 \%$ & Worthy \\
3. & Language aspect & $68 \%$ & & \\
\hline
\end{tabular}

Based on the table above, the results of the material expert validation assessment stage I obtained an average score of $71 \%$ which was stated with the "Eligible" criteria. In the material aspect, it gets a score of $75 \%$ with the "Eligible" criteria. Furthermore, the aspect of material presentation obtained a score of $70 \%$ with the criteria of "Eligible". Then the language aspect got a score of $68 \%$ with "Enough Decent". After the validation of the material expert phase I, the data obtained from the instrument assessment results that the media was revised with several criticisms and suggestions that had been given. The researcher on March 26, 2021 carried out the validation of the material expert phase II.

Table 2. Results of Phase 2 Material Expert Validation.

\begin{tabular}{clccc}
\hline No & \multicolumn{1}{c}{ Aspect } & Score & $\begin{array}{c}\text { Average } \\
\text { Score }\end{array}$ & Information \\
\hline 1. & $\begin{array}{l}\text { Load Aspect } \\
\text { Material }\end{array}$ & $90 \%$ & & \\
2. & $\begin{array}{l}\text { Presentation Aspect } \\
\text { Material }\end{array}$ & $90 \%$ & $90.6 \%$ & Very Worthy \\
2. & Language Aspect & $92 \%$ & & \\
\hline
\end{tabular}

Based on the table above, the results of the material expert validation assessment stage II obtained an average score of $90.6 \%$ which was stated with the "Very Eligible" criteria. In the material aspect, it gets a score of $90 \%$ with very good criteria. Furthermore, the aspect of material presentation obtained a score of $90 \%$ with very good criteria. Then the language aspect got a score of $92 \%$ with good criteria. After being validated by the material expert, it is followed by an expert. Media validation is carried out by a media design expert. The following are the results of product validation by media design experts.

Table 3. Validation Results of E-Book Media Design Experts Based on Local Culture.

\begin{tabular}{clccc}
\hline No & \multicolumn{1}{c}{ Aspect } & Score & $\begin{array}{c}\text { Average } \\
\text { Score }\end{array}$ & Information \\
\hline 1. & Aspects of content or content & $92 \%$ & & \\
2. & Display aspect & $95.38 \%$ & $91.43 \%$ & Very Worthy \\
3. & Aspects of use & $93.34 \%$ & & \\
4. & Language aspect & $85 \%$ & & \\
\hline
\end{tabular}


Based on table 3. above, the content aspect gets a score of $92 \%$ with the criteria "Very Eligible". Furthermore, the display aspect obtained a score of $95.38 \%$ with the "Very Eligible" criteria. Then the aspect of use obtained a score of $93.34 \%$ with the criteria of "Very Eligible". The language aspect with a total score of $85 \%$ with the criteria "Eligible". The results of the media expert validation assessment obtained an average score of $91.43 \%$ which was stated with the "Very Eligible" criteria. The stages of student evaluation are carried out after learning activities are carried out using an E-Book Based on the Local Culture of North Sumatra in the Higher Class Social Studies Education Course. The following are the results of the assessment of the use of the North Sumatran Local Culture-Based E-Book in the Higher Class Social Studies Education Course based on the pre-test and post-test scores as well as the results of the assessment instrument through student response questionnaires.

Table 4. Pre-test Results of Using Local Culture-Based E-Books in Higher Class Social Studies Education Courses.

\begin{tabular}{clccccc}
\hline No & Category & $\begin{array}{c}\text { Range } \\
\text { Mark }\end{array}$ & Frequency & $\begin{array}{c}\text { Amount } \\
\text { Mark }\end{array}$ & \% & Mean \\
\hline 1. & Very Complete & $95-100$ & - & - & - & \\
2. & Complete & $85-94$ & - & - & - & \multirow{2}{*}{ (2.88 } \\
3. & Enough Complete & $75-84$ & 6 & 465 & 23.1 & \\
4. & Not Complete & 75 & 20 & 1170 & 76.9 & \\
& Totally & & $\mathbf{2 6}$ & $\mathbf{1 6 3 5}$ & $\mathbf{1 0 0}$ & \\
\hline
\end{tabular}

Based on table 4. above shows that the students who scored in the "Enough Complete" category (75-84) were 6 students with a percentage of $23.1 \%$ with a total score of 465 . Furthermore, the scores included in the "Not Complete" category (amounted to 20 students) with a percentage of $76.9 \%$ with a total score of 1170 . The results of the pre-test scores obtained by students reached a total score of 1635 with an average score of 62.88 with the criteria "Not Complete". After the pre-test was carried out, the next step namely conducting a post-test final test to determine the level of achievement of student learning outcomes in the Higher Class Social Sciences Education Course.

Table 5. Pre-test Results of Using Local Culture-Based E-Books in Higher Class Social Studies Education Courses.

\begin{tabular}{rlccccc}
\hline No & Category & $\begin{array}{c}\text { Range } \\
\text { Mark }\end{array}$ & Frequency & $\begin{array}{c}\text { Amount } \\
\text { Mark }\end{array}$ & \% & Mean \\
\hline 1. & Very Complete & $95-100$ & 8 & 785 & 34.6 & \\
2. & Complete & $85-94$ & 13 & 1140 & 46.2 & \multirow{2}{\mathbf{88.65}}{} \\
3. & Enough Complete & $75-84$ & 4 & 315 & 15.4 & \\
4. & Not Complete & 75 & 1 & 65 & 3.8 & \\
\hline & Totally & & $\mathbf{2 6}$ & $\mathbf{2 3 0 5}$ & $\mathbf{1 0 0}$ & \\
\hline
\end{tabular}

Based on table 5. above, it shows that of the 26 students who scored in the "Very Complete" category (95-100) there were 8 students with a percentage of $34.6 \%$ with a total score of 785. Students who scored in the "Completed" category (85-94) ) totaled 13 students with a percentage of $46.15 \% \%$ with a total score of 1140 . Students who scored in the category of Complete Enough (75-84) were 4 students with a percentage of $15.3 \%$ with a total score of 
315. Furthermore, students who scored in the category "Unfinished" amounted to 1 person with a percentage of $3.8 \%$ with a total score of 65 . That the post-test scores obtained by students reached a total score of 2305 with an average score of 88.65 with the criteria of "Completed".

Table 6. The Results of the Difference Between Pre-Test and Post-Test in the Use Of E-Books Based on Local Culture in High Grade Social Studies Education Courses.

\begin{tabular}{clcc}
\hline No & \multicolumn{1}{c}{ Group } & Average value & Difference \\
\hline 1. & Pre-test (pretest) & 62.88 & 25.77 \\
2. & Final test (post test) & 88.65 & \\
\hline
\end{tabular}

The table above shows a comparison of the average value of the pre-test and post-test obtained 25.77 with an average pre-test of 62.88 stated with the criteria of "Not Completed" and the average post-test of 88.65 with the criteria of "Completed". The trial was carried out on class B Regular 2020 PGSD students by providing student response questionnaires to find out the practicality of using Local Culture-Based E-Books in Higher Class Social Studies Education Courses. The results of the student response assessment can be seen in the table below.

Table 7. Student Response Results Using E-Books Based on Local Culture in High Class Social Studies Education Courses.

\begin{tabular}{rllcl}
\hline No & \multicolumn{1}{c}{ Aspect } & Score & $\begin{array}{c}\text { Average } \\
\text { Score }\end{array}$ & Information \\
\hline 1. & Aspects of Interest & $82.69 \%$ & & \\
2. & Display Aspect & $83.58 \%$ & $80.28 \%$ & Practical \\
3. & Language Aspect & $77.69 \%$ & & \\
4. & Aspect of usability & $77.18 \%$ & & \\
\hline
\end{tabular}

Based on table 7 above, the results of the assessment of the student response instrument obtained an average score of $80.28 \%$ which was stated by the statement "Practical". On the aspect of interest, it scored $82.69 \%$ with the criteria of "Very Practical". Furthermore, the display aspect obtained a score of $83.58 \%$ with the criteria of "Very Practical". Then the language aspect obtained a score of $77.69 \%$ with the "Practical" criteria. The usability aspect with a total score of 77.18 with the criteria "Practical".

The development of Local Culture-Based E-Book products in Higher Class Social Studies Education Courses can assist lecturers in delivering information so that students can understand lectures more easily. In line with Sukmadinata's theory, research and development is a process or steps to develop a new product or improve an existing product, which can be accounted for. So researchers in developing E-Book products Based on Local Culture in Higher Class Social Science Education Courses were developed based on the absence of EBooks Based on Local Cultures that were used by lecturers in lecture activities at PGSD FIP UNIMED. So the researchers focused on developing E-Books Based on Local Cultures in Higher Class Social Studies Education Courses.

The data from the assessment results obtained from the validation of material experts in the first stage, namely getting a score of $71 \%$ with the "Eligible" criteria and with revisions. Referring to the criticisms and suggestions that have been given, the researchers carried out 
the second stage of validation and obtained a total score of $90.67 \%$ with the criteria of "Very Eligible" and without revision. Then the results of the expert assessment of the media design design validator as a media expert at this validation stage obtained a total score of $91.43 \%$ with the "Very Eligible" criteria and without revision and can be tested in schools. The average assessment results from the experts obtained were $84.3 \%$ with the criteria obtained, namely "Fair" and without revisions and learning media products can be tested.

The Practicality of Local Culture-Based E-Books in High Class Social Studies Education Courses based on the results of data obtained from student responses. Assessment of student responses based on aspects of interest, aspects of appearance, aspects of language, and aspects of learning. Then the average value of practicality is obtained that the Flash-based audiovisual learning media is categorized as "Practical" by obtaining an average value of $80.28 \%$. Based on the results of student data, practical criteria can be found, it states that E-Books Based on Local Culture in Higher Class Social Studies Education Courses are to be used in the online learning process. The results of the test of the effectiveness of the local culture-based E-Book learning media in the Higher Class Social Studies Education Course based on the implementation of the pre-test and post-test. From the data, students obtained complete learning outcomes, namely 80 . The results of pre-test students who completed were 5 students $(38.46 \%)$. After that, a post-test was carried out to obtain complete student data, namely as many as 25 students $(96.15 \%)$. Based on the data obtained from the results of the pre-test and post-test, there was an increase in student learning outcomes.

\section{Conclusion}

Based on the results and discussion of research on the development of Local CultureBased E-Books in Higher Class Social Studies Education Courses, it can be concluded as follows: Based on the results obtained in the research conducted that the development of Local Culture-Based E-Books in the Higher Class Social Studies Education Course, it was obtained that the feasibility of the material experts phase I was obtained, namely the percentage score of $71 \%$ with the criteria "Eligible" and the validation of the material experts in phase II obtained a score $90.68 \%$ with "Very Eligible" criteria. Then the assessment obtained from media experts is with a score of $92.67 \%$ with the criteria "Very decent" with no revision.

The data from the student response assessment based on the interest aspect, display aspect, language aspect, and learning aspect obtained an average score of $80.28 \%$ (Practical). So E-Books Based on Local Culture on High Class Social Studies Education Courses are good for students to use. Furthermore, the results of the pre-test carried out before using the Local Culture-Based E-Book in the Higher Class Social Science Education Course, it was found that 6 students had completed learning outcomes $(23.06 \%)$. For the results of the post-test test in the learning process using E-Books Based on Local Culture in the Higher Class Social Science Education Course, the student learning outcomes who completed as many as 25 people $(96.15 \%)$ It was found that student learning outcomes increased after using E-learning. Local Culture-Based Book on Higher Class Social Studies Education Courses.

\section{References}

[1] Mardapi D. Techniques for Preparation of Instruments and Nontests. Yogyakarta: Mitra Cendikia Offset; 2015. 13. 
[2] Belawati. Development of Teaching Materials. Jakarta: Publishing Center Open University; 2013. 23.

[3] Akker JVd. Principles and Methods of Development Research. On J. van den Akker, R.Branch, K. Gustafson, Nieven, and T. Plomp (eds), Design Approaches and Tools in Education and Training. Dortrech: Kluwer Academic Publishers; 1999. 1-14. s 